\title{
Inter-temporal patterns of R\&D collaboration and innovative performance
}

Citation for published version (APA):

Belderbos, R. A., Carree, M. A., Lokshin, B., \& Fernandez, J. (2015). Inter-temporal patterns of R\&D collaboration and innovative performance. Maastricht University, Graduate School of Business and Economics. GSBE Research Memoranda No. 004 https://doi.org/10.26481/umagsb.2015004

Document status and date:

Published: 01/01/2015

DOI:

10.26481/umagsb.2015004

Document Version:

Publisher's PDF, also known as Version of record

\section{Please check the document version of this publication:}

- A submitted manuscript is the version of the article upon submission and before peer-review. There can be important differences between the submitted version and the official published version of record.

People interested in the research are advised to contact the author for the final version of the publication, or visit the DOI to the publisher's website.

- The final author version and the galley proof are versions of the publication after peer review.

- The final published version features the final layout of the paper including the volume, issue and page numbers.

Link to publication

\footnotetext{
General rights rights.

- You may freely distribute the URL identifying the publication in the public portal. please follow below link for the End User Agreement:

www.umlib.nl/taverne-license

Take down policy

If you believe that this document breaches copyright please contact us at:

repository@maastrichtuniversity.nl

providing details and we will investigate your claim.
}

Copyright and moral rights for the publications made accessible in the public portal are retained by the authors and/or other copyright owners and it is a condition of accessing publications that users recognise and abide by the legal requirements associated with these

- Users may download and print one copy of any publication from the public portal for the purpose of private study or research.

- You may not further distribute the material or use it for any profit-making activity or commercial gain

If the publication is distributed under the terms of Article $25 \mathrm{fa}$ of the Dutch Copyright Act, indicated by the "Taverne" license above, 


\title{
Maastricht University
}

\author{
R. Belderbos, M. Carree, \\ B. Lokshin, J. Fernandez
}

Inter-temporal patterns of R\&D Collaboration and Innovative Performance

$\mathrm{RM} / 15 / 004$

\section{GSBE}

Maastricht University School of Business and Economics

Graduate School of Business and Economics

P.O Box 616

NL-6200 MD Maastricht

The Netherlands 


\title{
Inter-temporal patterns of R\&D Collaboration and Innovative Performance
}

\author{
René Belderbos ${ }^{\mathrm{a}}$, Martin Carree ${ }^{\mathrm{b}}$, Boris Lokshin $^{\mathrm{b}}$, Juan Fernández Sastre ${ }^{\mathrm{c}}$, \\ JEL-codes: O31, O32 \\ Keywords: R\&D collaboration, innovation, productivity
}

\begin{abstract}
While prior studies have investigated the effect of collaborative R\&D with different partner types (suppliers, customers, competitors and research institutions \& universities) on firms' innovative performance, the implications of dynamic patterns in these collaborations have not received attention. In a large panel of Spanish innovating firms operating in a broad range of industries during the period 2004-2011, we examine the differential effects of recently formed, persistent, and recently discontinued collaboration on innovative performance. Persistence is the most common pattern of collaboration, while discontinuities are most often observed for competitor collaboration. We find that it is persistent collaboration that has a systematically positive effect on performance. With the exception of recently formed collaboration with universities and research institutes, other temporal patterns of collaboration do not significantly improve performance. Implications of these findings are discussed.
\end{abstract}

\section{Corresponding Author}

René Belderbos

Department of Managerial Economics, Strategy and Innovation, University of Leuven,

Naamsestraat 69,

B-3000, Leuven, Belgium

Rene.Belderbos@kuleuven.be

${ }^{a}$ University of Leuven, Maastricht University, and UNU-MERIT

${ }^{\mathrm{b}}$ Maastricht University

${ }^{\mathrm{c}}$ Facultad Latinoamericána de Ciencias Sociales, Ecuador 


\section{Introduction}

Cooperation with industry and non-industry partners has been widely accepted as an important driver of firms' innovation performance. Collaboration can spur innovation because it allows access to external resources and knowledge that a firm may lack in-house (Chesbrough 2003; Dahlander and Gann 2010; Fey and Birkinshaw 2005). Recent empirical research has suggested that in order to better understand the performance consequences of $\mathrm{R} \& \mathrm{D}$ collaboration, it is important to differentiate between types of collaboration partners: vertical partners in the value chain such as suppliers and customers; competitors, and institutional partners (e.g. Aschoff and Schmidt 2008; Belderbos et al. 2006; Faria et al. 2010; Franco and Gussoni, 2014; Huang and Yu 2011). This distinction is imperative because of the different ways these various partner types have been shown to complement a focal firm's resources and capabilities (Belderbos et al. 2004b; Miotti and Sachwald 2003; Un et al. 2010; Santamaria and Surroca 2011).

Despite the growth of the literature on $R \& D$ collaboration and firm performance, little attention has been given to the innovation performance consequences of specific temporal patterns of R\&D collaboration: the formation of new collaborative ties, and the persistence or interruption of this collaboration ${ }^{1}$. Studies in strategic management drawing on technology alliance data have typically not been able to determine whether or when the technology alliances ended, while studies drawing on innovation survey data have met similar problems due to the absence of yearly surveys. Examining intertemporal patterns of collaboration is important, as they are likely to have differential performance implications.

The aim of this paper is to address this gap in extant research by examining in detail the performance consequences of three temporal patterns of $\mathrm{R} \& \mathrm{D}$ collaboration: recently formed collaboration, persistent collaboration, and recently discontinued collaboration. We examine this for

\footnotetext{
${ }^{1}$ There is a rather extensive body of research investigating the antecedents of failure of inter-firm partnering (e.g., Das and Teng 2000; Lhuillery and Pfister 2009; Parkhe 1993; Park and Ungson 2001; Saxton 1997). These studies, however, do not focus on the performance consequences of failure of inter-firm partnering. Belderbos et al. (2012) considered antecedents of persistence in collaboration. Lokshin et al. (2011) examined performance consequences of partnership malfunctioning but without differentiating among partner types or among temporal patterns of collaboration.
} 
collaboration with four different types of partners: customers, suppliers, competitors and universities \& research institutes. Empirically, we draw on panel data on a large sample of Spanish innovating firms operating (2004-2011). The data are collected from a Spanish innovation survey (PITEC) that, in contrast to other innovation surveys, is administered on a yearly basis. This allows examining dynamic patterns of start and termination of $R \& D$ collaboration. While persistent collaboration strategies are the most common, we find that competitor collaboration in particular exhibits noticeable dicontinuities. Performance effects are salient for persistent collaboration, although collaboration with research institutions and universities also provides performance benefits in the short term.

The remainder of this paper is organized as follows. The next section provides a succinct literature background for our analysis. We proceed by describing the data, sample, variables, and methods. After presenting empirical results, we discuss implications and conclude.

\section{Background and Prior Studies}

The resource-based-view perspective suggests that internal sources of technology development are often inadequate to cope with the increasing environmental complexity and speed of technological change (Barney 1991; Mahoney and Pandian 1992; Peterlaf 1993). Firms increasingly rely on external sources of knowledge that may account for a substantial share of the inputs that are necessary for the development of successful innovations (Chesbrough 2003; Fey and Birkinshaw 2005). Technological collaboration constitutes a prime vehicle in this knowledgesourcing process and companies therefore engage in collaboration with different partner types such as customers, suppliers, competitors and universities (e.g. Belderbos et al. 2004a 2004b; Enkel et al. 2005; Fritsch and Lukas 2001). The extant literature provides ample evidence on the performance consequences of R\&D collaboration (e.g. Becker and Dietz 2004; Dyer and Singh 1998; Singh and Mitchell 2005; Faems et al. 2005; Duysters and Lokshin 2011; Nieto and Santamaria 2007). 
The literature identifies a number of channels through which firm's technology collaboration activities can impact innovation performance. Collaboration with suppliers tends to contribute to innovation by increasing firm's knowledge of cost-reducing technologies, sharpening its focus on core competences, bettering design processes, and helping secure vital inputs (Amara and Landry 2005; Bruce et al. 1995; Suzuki 1993). Collaboration with suppliers can also create additional opportunities for the build-up of valuable, specific and difficult to imitate resources and competences, shared between a firm and its suppliers. This may provide a focal firm with the opportunity to steer its supplier's development efforts and thus influence its innovation competences (e.g. Ragatz et al. 1997). The effective integration of suppliers into new product development efforts can help firms achieve advantage over competitors in terms of the cost of new product development, utilized technologies and development time. Such supplier involvement has been shown to increase product innovation in mature industry segments (Eisenhardt and Tabrizi 1994), and can help firms realize higher process efficiencies (Saeed et al. 2005). In addition, there is evidence that collaboration with suppliers may reduce risk and lead times of product development (Chung and Kim 2003; Nieto and Santamaria 2007).

Collaboration with customers can facilitate market acceptance and commercialization of (product) innovations. Customers have been found to be instrumental in reducing the risks associated with the market introduction of new products, and particularly in the presence of heterogeneous market needs, and when technology is 'sticky' (Sanchez-Gonzales et al. 2009; von Hippel and Katz 2002) or when the new products require adaptations for their usage due to their complexity or novelty (Tether 2002; Von Hippel 1988). Customer collaboration may help improve firm's understanding of their customers' unmet (future) needs, increase the attractiveness of their products and possibly extend the product or process life cycle (Herstatt and von Hippel 1992; Jeppsen and Molin 2003; Tidd et al. 2005). In addition, firms that collaborate with customers may develop new competences that are required for the realization of shorter lead times and market 
responsiveness (Choi and Hartely 1996; Childerhouse et al. 2002; Harabi 2001), facilitating the innovation process.

Collaboration with competitors can contribute to the creation of new-to-the-market innovations by creating access to scarce, external expertise on promising new technologies that precede application in future markets (Hagedoorn 2002). Typically, research consortia fall into this category, where competitors work together in order to share the costs and risks of research, pool scarce expertise and equipment and aim to develop far-from-market technology with generic application potential (Miotti and Sachwald 2003; Tidd et al. 2005). Collaboration with competitors can help resolve common technological issues, for instance in the development of industry standards (Gnyawali and Park 2011).

Collaboration with universities and research institutes may spur the creation of radical, nextgeneration innovations (Belderbos et al. 2004b; Tidd et al. 2005) by providing an important source of state-of-the-art, technological knowledge. Such collaboration can lead to the development of new applications of already existing technology and/or of radically new technology (Archibugi and Coco 2004; Drejer and Jorgensen 2005; Arvanitis et al. 2008). Engaging in university collaboration can be attractive for firms since it allows inexpensive and low-risk access to specialist knowledge and generic, basic R\&D (Arranz and Arroyabe 2008; Azagra-Caro, et al., 2014; Beers et al. 2008; Mototashi 2005; Woerter, 2012). Academic research, carried out by universities and public research organizations, has been shown to be complementary to a firm's own innovation activities, thus significantly contributing to its ability to create innovations (Tether and Tajar 2008; Baba et al. 2009). There are estimates that as much as $15 \%$ of new products would not have been developed by firms in the absence of recent academic research (Mansfield 1998). Jiang et al. (2010) find that in early stages of the industry life cycle, the exploration of scientific knowledge in the public domain is instrumental in achieving innovation success. Thursby and Thursby (2002) also emphasize the importance of university collaboration in creating impactful innovations. Collaboration with universities and research institutes facilitates access to national and international knowledge 
networks (Okubo and Sjöberg 2000) and may support the hiring and selection of talented graduates and doctoral researchers. At the same time, collaboration with universities and research institutes can contribute to technical problem solving that may be beneficial for process innovations (Cohen et al. 2002).

\section{Intertemporal patterns of $R \& D$ collaboration}

While the above discussion suggests ways in which R\&D collaboration can enhance innovative performance, differential effects due to specific temporal patterns of collaborative activity are not considered. In the following, we distinguish among newly formed, persistent and discontinued collaboration and argue that they are likely to differ in terms of performance implications.

A recently started collaboration may not yield immediate performance effects as it may take a certain 'incubation' period before a partnership materializes and starts to contribute to a firm's innovation performance. This consideration may however be different depending on the type of partner. Collaboration with clients and suppliers is likely to have a 'problem solving' background and lead to relatively short research and development trajectories resulting in relatively fast 'solutions', while competitor collaboration focusing on pre-competitive research is likely to have a longer trajectory. For collaboration with universities and research institutes the patterns may be mixed. Projects focusing on basic and applied research are likely to have a longer time frame, but projects enlisting institutes to solve technological problems faced by the firms can have immediate results.

Extant literature suggests that firms collaborating persistently with a particular type of partner are particularly well-placed to reap the benefits from inter-firm partnering, since these firms are likely to have refined their (inter)organizational routines for collaboration and have gained experience in managing that type of inter-firm relationships (Das and Teng 2000). Persistent collaboration can be attractive as effective learning takes place through repeated collaboration that 
allows for the build-up of trust (Gulati 1995), supporting the exchange of tacit and fine-grained information and knowledge (Gilsing and Nooteboom 2006). The learning effects achieved through continuity in R\&D collaboration can increase the efficiency of partnering strategies (Faems et al. 2008; Nieto and Santamaria 2007). Furthermore, persistent collaboration may signal that a company is not only a competent partner that disposes over valuable and scarce expertise but is also reliable and trustworthy. This may contribute to the build-up of a reputation as a reliable and attractive partner, which may reduce risks of partner opportunism and negative referrals or lock-out from future collaborative opportunities (Nooteboom 2004). These reputational effects suggest that firms that collaborate more persistently may on average be able to collaborate with more competent partners, boosting the performance effects of their R\&D ties.

The termination of collaboration may on the one hand simply indicate that a partnership has accomplished its goals. On the other hand, termination may indicate that collaborative efforts have not been successful which is likely to lead to delays in the introduction of new products and technologies (Lhuillery and Pfister 2009). Such failure is reported to be a rather frequent outcome of inter-firm collaboration, with unsuccessful collaboration rates between 30-50 percent reported (e.g. Bleeke and Ernst 1991; Harrigan 1988; Killing 1988). Partnership malfunctioning has been shown to be harmful for firms' ability to create innovations and/or to bring innovations to the market (Lokshin et al. 2011). If malfunctioning is a driver of discontinued collaboration, this will delay or complicate the absorption of knowledge necessary for the successful completion of firms' innovation projects. Overall, this suggests ambiguous effects of discontinued R\&D collaboration.

In sum, we expect that collaboration with each type of cooperation partners can bring in complementary inputs to firms' innovation processes, suggesting that they can jointly contribute to innovative performance. Furthermore, we expect that persistent collaboration is most strongly associated with innovative performance, while discontinued collaboration is the least likely to be associated with improved innovative performance. We examine these relationships empirically in a large panel of Spanish firms. 


\section{Empirical model, Data and Methods}

We estimate a dynamic performance model in which we examine the influence of intertemporal patterns of collaboration with customers, suppliers, competitors and universities \& research institutes on firms' innovative performance. In order to test for the impact of recent, persistent and discontinued collaboration on innovation performance we relate innovative performance in year t to recent, persistent and discontinued collaboration with each of the four partner types evaluated in year $\mathrm{t}-1$. We include lagged innovation performance to arrive at a dynamic specification. Innovation has been found to be a persistent phenomenon, as it is derived from firms' resources and capabilities that are cumulative in nature (Raymond et al 2010). Our estimation equation is as follows:

$$
\begin{aligned}
& \ln \left(\text { InnoPerf }_{i, t}\right)=\alpha+\sum_{j=1}^{4} \beta_{1}^{j} \operatorname{NewCoop}_{j, i, t-1}+\sum_{j=1}^{4} \beta_{2}^{j} \operatorname{ContCoop}_{j, i, t-1}+ \\
& \quad+\sum_{j=1}^{4} \beta_{3}^{j} \text { DiscontCoop }_{j, i, t-1}+\gamma W_{i, t-1}+\delta \ln \left(\text { InnoPerf }_{i, t-1}\right)+\lambda_{t}+\mu_{i}+\varepsilon_{i, t}
\end{aligned}
$$

where $j$ is collaboration with customers, suppliers, competitors, or universities and research institutes. The variable InnoPerf is innovative performance, $W$ stands for a set of control variables, $\varepsilon$ is the error term, $\mu_{\mathrm{i}}$ are industry dummies and $\lambda_{\mathrm{t}}$ are time dummies. We expect the coefficient on lagged innovative performance, $\eta$, to fall within the interval $[0,1]$. If $\eta$ is greater than zero, there is a degree of persistence in innovative performance. We can interpret the model as a partial Granger causality model, with the number of lags limited to one. The estimates for $R \& D$ collaboration indicate if collaboration explains innovative performance over and above the effect of persistence.

We estimate equation (1) using least squares with robust (clustered) standard errors. Incorporating random- or firm-specific fixed effects next to the lagged dependent variable in a short 
panel would introduce important estimation bias. The lagged innovative performance should pick up a substantial amount of otherwise unobserved firm heterogeneity, while the analysis includes an elaborate set of control variables (see below). The short time dimension, unbalanced nature of the panel, and large number of focal variables of interest makes it problematic to embark on dynamic panel instrumental variable estimation techniques such as GMM.

\section{Data and variables}

The empirical analysis uses data from the Spanish Survey of Technological Innovation PITEC (Panel de Innovación Tecnológica). The survey is carried out by the Spanish National Statistics Institute (INE), the Spanish Foundation for Science and Technology (FECYT) and the Foundation for Technological Innovation (COTEC). The annual data, from 2004 until 2011, were collected at the establishment level and contain information on firms' innovation activities. The survey covers firms operating in all sectors of the Spanish economy. The PITEC questionnaire, similar to the Community Innovation Survey, has a multi-layer structure. Only those firms that report to be engaged in innovative activities are asked to complete the entire questionnaire and are the focus of our analysis. Given the partially random sampling in each year for smaller firms, many firms are not observed for the entire period and the panel is unbalanced in nature. Our analysis focuses on firms in manufacturing and services industries, and requires that we observe a firm at least 3 consecutive years: innovative performance in year $t$, and intertemporal patterns of collaboration derived from survey information in years $t-1$ and $t-2$. This resulted in a dataset covering 9782 firms, for which we jointly have 42896 observations.

The dependent variable is defined as the logarithm of the ratio of sales from products that are new to the market divided by the total number of employees (e.g. Belderbos et al 2004b). Sales of innovative products is an appropriate and often used indicator of innovations that have successfully found their way to the market. New to the market products can be seen as more 'radical' in the sense that products are not just new to the firm, but also putting the firm ahead in its 
industry. The scaling by the number of employees to arrive at a productivity measure assures that this is not a size-related effect and that the efficiency of the innovative process (where collaboration will play a key role) is taken into account.

The analysis distinguishes between recently established, persistent, and discontinued collaboration. Recent collaboration is defined as engagement in collaboration in the survey in year $\mathrm{t}-1$ but not in the survey in year $\mathrm{t}-2$. Persistent collaboration is defined as collaboration in the two consecutive yearly surveys in $\mathrm{t}-1$ and $\mathrm{t}-2$, and discontinued collaboration is defined as collaboration in the survey in year $\mathrm{t}-2$ but not in year $\mathrm{t}-1$. Preferably we would have examined longer survey lags, but given the limited panel structure of the data, there is little scope to extend the time dimension.

In addition to lagged innovative performance, we control for innovation expenditures as key inputs into the innovation process. Innovation expenditures do not only cover outlays on $\mathrm{R} \& \mathrm{D}$ (intramural $R \& D$ and expenditures on external $R \& D$ such as $R \& D$ contracting) but also extend to expenditures on the marketing and design of innovations. Innovation expenditures are scaled by sales. We control for firm size, measured as the logarithm of the firm's number of employees (Cohen and Klepper 1996) ${ }^{2}$ and for the export status of the firm. We may expect that exporters are more innovative than non-exporters, all else being equal, as pressure to innovate and renew products is greater for firms competing in international markets. We also include a resource constraints variable that refers to factors hampering the innovation process of the firm. The literature is divided on the role of resource constraints with some contributions finding a negative effect (e.g. Mohnen and Roller 2006) while others prescribe them a role of a trigger for innovation (Keupp and Gassman 2013). To measure resource constraints, we take the sum of dummies that take value one (else zero) if firms report bottlenecks in the innovation process caused by high costs or lack of financial resources; uncertainty about market conditions; and organizational bottlenecks

\footnotetext{
${ }^{2}$ We also estimated nonlinear relationships between firm size and innovation performance by including a quadratic term of size, but its coefficient was insignificant while the linear term remained significantly positive. Similarly, F-tests conducted on the coefficients of interests after performing split sample analysis for small and medium sized firm versus larger firms showed no significant differences between the two samples.
} 
that capture firm's shortage of qualified (R\&D) personnel. ${ }^{3}$ Patent productivity is defined as the ratio of the number of patent applications in the past three years over innovation expenditures. The variable controls for firms' past technological activities, as well as for differences in technological performance after controlling for inputs into the innovation process. Finally, we include the sets of industry dummies and year dummies.

\section{Descriptive statistics}

Table 1 displays the distribution of collaborative ties over partner types and temporal pattern of collaboration. Supplier and institutional collaboration are most prominent, while collaboration with competitors and customers is observed much less frequently. Persistent collaboration is more frequently observed than new or discontinued collaboration and takes up about half of the observations on collaboration, except for competitor collaboration (41 percent). There are other differences in the intertemporal pattern of collaboration depending on the partner type, with persistent collaboration more often reported for supplier and institutional partnerships. Discontinuation of competitor collaboration is relatively more frequent than discontinued collaboration with other partner types, and represents almost 32 percent of the observations on competitor collaboration. In addition, it is of interest to report that 1853 firms representing about 12 percent of the sample observations report at least one type of collaboration (not in Table 1).

\section{INSERT TABLE 1}

Table 2 presents the descriptive statistics for the variables used in the estimation. The average firm size is 300 employees (median firm size is 52 employees) and has a R\&D intensity of about 5 percent. About 70 percent of the firms are exporters. Lagged and current innovative

\footnotetext{
${ }^{3}$ We note that exporting may also be the result of successful innovation, implying reverse causality. Since export status is measured in year $\mathrm{t}-1$ and innovative performance in year $\mathrm{t}$, this concern is mitigated. Excluding export status does not materially affect the estimation results for the focal variable, while the results indicate that it does have consequences for subsequent innovative performance.
} 
performance are highly correlated, as expected, with a correlation coefficient of 0.67 . Correlations between innovative performance and prior collaborations are all positive with the highest correlations for persistent supplier collaboration and persistent institutional collaboration. The only negative correlation of innovative performance is, unsurprisingly, with resource constraints. The correlation table does not suggest multicollinearity concerns.

\section{INSERT TABLE 2}

\section{Empirical results}

The results of the model analyzing the effect of R\&D collaboration on firms' innovative performance are displayed in Table 3. Model 1 shows the results of a base model with control variables only. In model 2 the R\&D collaboration variables are included. The likelihood ratio (LR) test shows a significant improvement in the fit of the model when including the R\&D collaboration variables. The results show that innovative performance exhibits a strong persistence: the coefficient of 0.64 for past innovative performance suggests that 64 percent of firms' prior innovative productivity is maintained in the subsequent period. Larger firms, firms with relatively high innovation expenditures, and exporting firms show significantly stronger innovative performance. Resource constraints have a negative effect suggesting that some of the innovations ambitions have been hampered due to a lack of financial or human resources.

Turning to the effects of prior $\mathrm{R} \& \mathrm{D}$ collaboration, we observe that discontinued collaboration has no significant impact on innovative performance no matter the type of partner. Recent collaboration has a significant effect if it concerns collaboration with institutional partners, while persistent collaboration significantly improves innovative performance for all partners: customer, supplier, competitor or research institutes \& universities. The most salient effect is observed for persistent competitor collaboration: the coefficient of 0.229 implies that competitor 
collaboration increases performance by approximately 23 percent. ${ }^{4}$ For supplier collaboration, which has the smallest estimated coefficient, the estimated effect is close to 12 percent.

We also examined the differential impact between the temporal patters of $R \& D$ collaboration more formally by examining whether the sum of coefficients of the persistent collaboration variables was greater than the sum of coefficients of the recent and discontinued collaboration variables, respectively. The hypotheses that these sum of coefficients are equal was rejected at the 5 percent level for recent collaboration and at the 1 percent level for discontinued collaboration The results thus suggest a ranking of effects from persistent, to recent, to discontinued collaboration.

\section{INSERT TABLE 3}

\section{Conclusions}

This paper contributes to the literature on $\mathrm{R} \& \mathrm{D}$ collaboration and performance by examining the heterogeneous performance effects of dynamic patterns of $R \& D$ collaboration with different partner types (suppliers, customers, competitors and universities \& research institutions). In contrast with prior studies, we are able to determine both the start and termination of collaborative activities, facilitating the analysis of dynamic relationships. We argue that differential performance consequences are to be expected of specific intertemporal patterns of collaboration. Empirically, we draw on yearly panel data on a large set of Spanish innovating firms, 2004-2011 and measure innovative performance as sales of newly improved and introduced products per employee.

Estimation of a dynamic performance model shows that, taking account of the fact that innovative performance is strongly related to past innovative performance (e.g. Raymond et al.,

\footnotetext{
${ }^{4}$ Given that the dependent variable is the natural logarithm of innovative performance (the sales due to innovative products per employee) the coefficients of the dummy variables represent approximately the proportional increase in innovative performance due to collaboration: $\beta=\frac{d \ln y}{d x}=\frac{d y / y}{d x}$.
} 
2010), R\&D collaboration can generate a significant performance premium. Collaboration with all types of partners improves performance once firms have been persistently engaged in collaborating with that type of partner. The strongest effect is estimated for R\&D collaboration with competitors, which can improve performance by 23 percent, and the smallest effect is estimated for supplier collaboration (12 percent). Discontinued collaboration does not affect performance, while recently started (in the prior year) collaboration has a positive effect on performance only if it concerns partnership with universities or research institutions.

The results are consistent with the notion of a necessary 'incubation time' before new collaborative ties in $R \& D$ can add to effective innovative performance. The consistently important role of persistent collaboration are also in line with suggested benefits of collaboration experience and the reputational effects for the firm through establishing itself as a reliable and committed collaboration partner. The positive effect of recent $R \& D$ collaboration with institutions is likely to be due to the dual nature of such collaboration: collaboration can focus on applied and basic research but also frequently includes more limited collaboration focusing on technological problem solving (e.g. Cohen et al., 2002). Our findings with respect to university collaboration are consistent with other recent studies on Spanish firms using PITEC data (e.g. Diez-Vial and Fernandez-Olmos, 2014) which suggested that institutional collaboration helps firms develop capacity to understand and utilize basic research and to better capture positive externalities generated by public research organizations and universities.

While we did not observe a negative effect of discontinued collaboration, the results are consistent with the notion that termination or interruption of R\&D collaboration may not only reflect achievement of collaboration goals, but also frequently finds its cause in coordination failure and partnership malfunctioning (Lhuillery and Pfister 2009; Lokshin et al. 2011; Das and Teng 2000). Given that there may be a longer term strategic need to access complementary expertise of 
the specific type of partner, discontinuation of collaboration is likely to impede the firm in reaching the innovation goals set for that type of R\&D partnership.

The key implication for extant research on $R \& D$ collaboration is that intertemporal patterns of R\&D collaboration matter for performance, although they are typically not identified in empirical studies (e.g. Gulati, 1995; Lavie and Miller, 2008, Hoang and Rothaermel, 2010). On the one hand, it suggests merits of the common approach in the literature on technology alliances to take 3 or 5 year 'portfolios' of alliances into account (counting alliances started in the last 3 to 5 years) - in the absence of information on termination. On the other hand, such portfolios will hide substantial heterogeneity in collaboration in terms of persistence and discontinuation. If such patters are systematically different across types of alliances, then results of empirical analysis will be biased. The same implication applies to studies using innovation surveys to measure R\&D collaboration (e.g. Belderbos et al., 2004b; Un et al., 2010; Nieto and Santamaria, 2011): differential performance effects of collaboration across partner types may be due to underlying differences in temporal partners of such collaboration, rather than to different effects of collaboration as such. In this respect, there is an important heterogeneity between $R \& D$ collaboration partners with different partner types. Specifically, we observed much less persistence and more frequent interruption of collaboration with competitors compared with the pattern of collaboration with other partner types. The latter finding may indicate the greater challenges of such collaboration due to the more complex governance issues and appropriability concerns (e.g. Belderbos et al., 2012) leading to more frequent partnership malfunctioning. It could also partially be explained by the greater focus on pre-competitive development of further-from-market technology in competitor collaboration, with longer term ties extending to joint product development often restricted due to competition policy (Teece, 1980; Belderbos et al., 2006; Bolli and Woerter, 2013; Tether 2002).

Our research is not without limitations. A number of aspects of the collaboration patterns may be specific to the data on Spanish firms that we analyzed. In Spain, the majority of the national R\&D effort is carried out by the public sector. Firms are therefore likely to have relatively strong 
incentives to cooperate with research institutions, and such collaboration is often supported by public policies. This may explain why institutional collaboration is rather well represented in our sample and why collaboration with institutions is observed to have a limited 'incubation time' until it affects innovative output. We suggest that future work examines the patterns of dynamic interrelation and performance drawing on innovation surveys in other countries to investigate the generalizability of our findings. Second, our analysis of dynamics was limited to two years of prior collaboration. The relatively small time dimension in our unbalanced panel precluded us from taking a longer view on dynamic collaboration patterns. Future research should aim to investigate longer term patterns of collaboration, employing data with a longer time dimension. Third, our data describe dynamic patterns of collaboration by type of partner, but do not provide detail on individual collaborations at the individual partner level. This is a defining feature of innovation surveys in general and is not easily addressed given the confidentiality and anonymous nature of the data. It does call for efforts to collect and analyze data on dynamic patterns of start and termination of R\&D collaboration at the 'dyadic' collaboration level in future work.

\section{REFERENCES}

Amara, N., \& Landry, R. (2005). Sources of information as determinants of novelty of innovation in manufacturing firms: evidence from the 1999 Statistics Canada Survey of Innovation. Technovation, 25, 245-259.

Archibugi, D., \& Coco, A. (2004). International partnerships for knowledge in business academia: a comparison between Europe and USA. Technovation, 24(7), 517-528.

Arranz, N., \& Arroyabe, J. (2008). The choice of partners in R\&D cooperation: an empirical analysis of Spanish firms. Technovation, 28, 88-100.

Arvanitis, S., Kubli, U., \& Woerter, M. (2008). University-industry knowledge and technology transfer in Switzerland: What university scientists think about collaboration with private enterprises. Research Policy, 37(10), 1865-1883.

Aschhoff, B., \& Schmidt, T. (2008). Empirical evidence on the success of R\&D collaboration Happy together? Review of Industrial Organization, 33(1), 41-62. 
Azagra-Caro, J.,Pardo, R., Rama, R. (2014). Not searching, but finding: how innovation shapes perceptions about universities and public research organisations. Journal of Technology Transfer, forthcoming

Baba, Y., Shichijo, N., \& Sedita, S. (2009). How do collaborations with universities affect firm's innovative performance? The role of "Pasteur scientists" in the advanced materials field. Research Policy, 38, 756-764.

Barney, J. (1991). Firm resources and sustained competitive advantage. Journal of Management, 17(1), 99-120.

Becker, W. \& Dietz, J. (2004). R\&D cooperation and innovation activities of firms-evidence for the German manufacturing industry. Research Policy 33(2), 209-223.

Beers, C., Berghall, E., \& Poot, T. (2008). R\&D internationalization, R\&D collaboration and public knowledge institutions in small economies: Evidence from Finland and the Netherlands. Research Policy, 37, 294-308.

Belderbos, R., Gilsing, V., \& Lokshin, B. (2012). Persistence of, and interrelation between horizontal and vertical technology alliances. Journal of Management, 38(6), 1788-1811.

Belderbos, R., Carree, M., \& Lokshin, B. (2004b). Cooperative R\&D and firm performance. Research Policy 33, 1477-1492.

Belderbos, R., Carree, M., \& Lokshin, B. (2006). Complementarity in R\&D collaboration strategies. Review of Industrial Organization 28, 401-426.

Belderbos, R., Carree, M., Diederen, B., Lokshin, B., \& Veugelers, R. (2004a). Heterogeneity in R\&D collaboration strategies. International Journal of Industrial Organization, 22(8-9), 12371263

Bleeke, J., \& Ernst, D. (1991). The way to win in cross-border alliances. Harvard Business Review, 69(6), 127-35.

Bolli, T., \& Woerter, M. (2013). Competition and R\&D cooperation with universities and competitors. Journal of Technology Transfer, 38(6), 768-787.

Bruce, M., Leverick, F., Littler, D., \& Wilson, D. (1995). Success factors for collaborative product development: a study of suppliers of information and communication technology. R\&D Management, 25(1), 33-44.

Cassiman, B., \& Veugelers, R. (2006). In search of complementarity in innovation strategy: Internal $R \& D$, collaboration in $R \& D$ and external technology acquisition. Management Science 52(1), 68-82.

Chesbrough, H.W. (2003). Open Innovation: The new imperative for creating and profiting from technology. Boston, MA.: Harvard Business School Press. 
Childerhouse, P., Aitken J., \& Towell, D. (2002). Analysis and design of focused demand chains. Journal of Operations Management, 20, 675-689.

Choi, T. \& Hartley J. (1996). An exploration of supplier selection practices across the supply chain. Journal of Operations Management, 14(4), 333-343.

Chung, S., \& Kim, G.M. (2003). Performance effects of partnership between manufacturers and suppliers for new product development: the suppliers standpoint. Research Policy, 32(4), 587-603.

Cohen, W., Nelson, R., \& Walsh, J. (2002). Links and Impacts: The Influence of Public Research on Industrial R\&D. Management Science, 48(1), 1-23.

Cohen, W.M., \& Klepper, S. (1996). Firm size and the nature of innovation within industries: the case of process and product R\&D. Review of Economics and Statistics, 78(2), 232-243.

Dahlander, L ., \& Gann, D.M. (2010). How open is innovation? Research Policy, 39(6), 699-709.

Das T. K. \& Teng, B. S. (2000). Instabilities of strategic alliances: an internal tensions perspective Organization Science, 11(1), 77-101.

Diez-Vial, I. and Fernandez-Olmos, M. (2014). Knowledge spillovers in science and technology parks: how can firms benefit most?, Journal of Technology Transfer, in press.

Drejer, I., \& Jorgensen, B., (2005). The dynamic creation of knowledge: analyzing public-private collaborations. Technovation, 25, 83-94.

Duysters G.M., \& Lokshin, B. (2011). Determinants of alliance portfolio complexity and its effect on innovative performance of companies. Journal of Product Innovation Management, 28(4), $270-285$

Dyer, J.H., \& Singh,H. (1998). The relational view: Cooperative strategy and the sources of inter organizational advantage. Academy of Management Review, 23(4), 660-679.

Eisenhardt, K., \& Tabizi, B. (1994). Accelerating adaptive processes: product innovation in the global computer industry. Administrative Science Quarterly, 40, 84-110.

Enkel, E., Gassmann, O., \& Chesbrough, H. (2009). Open R\&D and open innovation: exploring the phenomenon. R\&D Management, 39 (4), 311-316.

Faems, D., Janssens, M., Madhok, A., \& Van Looy, B. (2008). Towards an integrative perspective on alliance governance: Connecting contract design, contract application and trust dynamics. Academy of Management Journal 51(6), 1053-1078.

Faems, D., Van Looy, B., \& Debackere, K. (2005). Interorganizational collaboration and innovation: Toward a portfolio approach. Journal of Product Innovation Management, 22(3), $238-250$. 
Faria, P., Lima, F., \& Santos, R. (2010). Cooperation in innovation activities: the importance of partners, Research Policy 39, 1082-1092.

Fey, C.F., \& Birkinshaw, J. (2005). External sources of knowledge, governance mode, and R\&D performance. Journal of Management, 31(4), 597-621.

Franco, C., and Gussoni, M. (2014). The role of firm and national level factors in fostering R\&D cooperation: a cross country comparison, Journal of Technology Transfer, forthcoming.

Fritsch, M., \& Lukas, R. (2001). Who cooperates on R\&D? Research Policy, 30(2), 297-312.

Gilsing, V, \& B. Nooteboom. (2006). Exploration and exploitation in innovation systems: the case of pharmaceutical biotechnology, Research Policy, 35, 1-23.

Gnyawali, D.R., \& Park, B.J. (2011). Co-opetition between giants: Collaboration with competitors for technological innovation. Research Policy, 40, 650-663.

Gulati, R. (1995). Does Familiarity Breed Trust? The Implications of Repeated Ties for Contractual Choice in Alliances. Academy of Management Journal, 38(1), 85-112.

Hagedoorn, J. (2002). Inter-firm R\&D partnerships: an overview of major trends and patterns since 1960. Research Policy, 31, 477-492.

Harabi, N. (2002). The impact of vertical R\&D cooperation on firm innovation: an empirical investigation, Economics of Innovation and New Technology, 11(2), 93-108

Harrigan K. (1988). Strategic alliances and partner asymmetries. In F. Contractor, P. Lorange (Eds.), Cooperative Strategies in International Business (pp. 205-26). New York: Lexington Books.

Herstatt, C., \& von Hippel, E. (1992). From experience: developing new product concepts via the lead user method: a case study in a "low-tech" field. Journal of Product Innovation Management, 9, 213-221.

Hoang, H., \& Rothaermel, F.T. (2010). Leveraging internal and external experience: Exploration, exploitation, and R\&D project performance. Strategic Management Journal, 31(7), 734-758.

Huang, K.-F., \& Yu, C.-M. J. (2011). The effect of competitive and non-competitive R\&D collaboration on firm innovation. The Journal of Technology Transfer, 36(4), 383-403.

Jeppesen, L.B., \& Molin, M.J. (2003). Consumers as co-developers: Learning and innovation outside the firm. Technology Analysis \& Strategic Management, 15(3), 363-83.

Jiang, L., Tan, J., \& Thursby, M.C. (2011). Incumbent firm innovation in emerging fields: Evidence from the semiconductor industry. Strategic Management Journal, 32(1), 55-75.

Keupp, M.M., \& Gassmann, O. (2013). Resource constraints as triggers of radical innovation: Longitudinal evidence from the manufacturing sector. Research Policy, 42(8), 1457-1468. 
Killing, J.P. (1988). Understanding alliances: the role of tasks and organizational complexity. In F. Contractor, P. Lorange, eds. Cooperative Strategies in International Business. Lexington Books, pp. 55-68.

Lavie, D., \& Miller, S.R. (2008). Alliance portfolio internationalization and firm performance. Organization Science, 19(4) 623-646.

Lhuillery, S., \& Pfister, E. (2009). R\&D cooperation and failures in innovation projects: Empirical evidence from French CIS data. Research Policy, 38(1), 45-57.

Lokshin, B., Hagedoorn, J., \& Letterie, W. (2011).The Bumpy Road of Technology Partnerships: Understanding causes and consequences of partnership mal-functioning. Research Policy, 40(2), 297-308.

Mahoney, J.T., \& Pandian, J.R. (1992). The resource-based view within conversation of strategic management. Strategic Management Journal, 13(5), 363-380.

Mansfield, E. (1998). Academic research and industrial innovation: An update of empirical findings. Research Policy, 26(7-8), 773-776.

Miotti, L., \& Sachwald, F. (2003). Co-operative R\&D: why and with whom?: and integrated framework of analysis. Research Policy, 32(8), 1481-1499.

Mohnen, P., \& Roller, L.-H. (2005). Complementarities in innovation policy. European Economic Review, 49(6), 1431-1450.

Mototashi, K. (2005). University-industry collaborations in Japan: The role of new technologybased firms in transforming the National Innovation System. Research Policy, 34(5), 583-594.

Nieto, M.J., \& Santamaria, L. (2007). The importance of diverse collaborative networks for the novelty of product innovation. Technovation, 27(6), 367-377.

Nooteboom, B. (2004). Inter-firm collaboration, learning and networks: an integrated approach. London: Routledge Taylor \& Francis Group.

Okubo,Y., \& Sjöberg, C. (2000). The changing pattern of industrial scientific research collaboration in Sweden. Research Policy, 29(1), 81-98.

Parkhe, A. (1993). Strategic alliance structuring: a game theoretic and transaction cost examination of interfirm cooperation. Academy of Management Journal, 36(4), 794-829.

Peterlaf, M.A. (1993). The cornerstones of competitive advantage: a resource-based view. Strategic Management Journal, 14(3), 179-191.

Ragatz, G., Handfield, R.B., \& Scannel, T.V. (1997). Success factors for integrating suppliers into new product development. The Journal of Product Innovation Management, 14(3), 190-202.

Raymond, W., Mohnen, P., Palm, F., \& Schim van der Loeff, S. (2010). Persistence of Innovation in Dutch Manufacturing: Is It Spurious? Review of Economics and Statistics, 92(3), 495-504. 
Saeed, K., Malhotra, M.K., \& Grover, V. (2005). Examining the impact of inter-organizational systems on process efficiency and sourcing leverage in buyer-supplier dyads. Decision Sciences, 36(3), 365-396.

Sánchez-Gonzáles, G., Gonzáles-Álvares, N., \& Nieto, M. (2009). Sticky information and heterogeneous needs as determining factors of R\&D collaboration with customers. Research Policy, 38(10), 1590-1603.

Santamaria, L., \& Surroca, J. (2011). Matching the goals and impacts of R\&D collaboration. European Management Review, 8(2), 95-109.

Saxton, K. (1997). The effects of partner and relationship characteristics on alliance outcomes. The Academy of Management Journal, 40(2), 443-461.

Singh, K., \& Mitchell, W. (2005). Grow Dynamics: the bidirectional relationship between interfirm collaboration and business sales in entrant and incumbent alliances. Strategic Management Journal, 26(6), 497-521.

Suzuki, K. (1993). R\&D Spillovers and Technology Transfer Among and Within Vertical Keiretsu Groups: Evidence from the Japanese Electrical Machinery Industry. International Journal of Industrial Organization, 11(4), 573-591.

Teece, D. J. (1980). Economics of scope and the scope of the enterprise. Journal of Economic Behavior and Organization, 1(3), 223-247.

Tether, B.S. (2002). Who co-operates for innovation, and why: an empirical analysis. Research Policy, 31(6), 947-967.

Tether, B.S., \& Tajar, A. (2008). Beyond industry-university links: Sourcing knowledge for innovation from consultants, private research organizations and the public science-base. Research Policy, 37(6-7), 1079-1095.

Thursby, M.C., \& Thursby, J.G. (2002). Who is selling the ivory tower? Sources of growth in university licensing. Management Science,48(1), 90-104.

Tidd, J., Bessant, J., \& Pavitt, K. (2005). Managing innovation: Integrating technological, market and organizational change. Chichester: John Wiley \& Sons.

Un, C.A, Cuervo-Cazurra, A., Asakawa, K. (2010). R\&D collaboration and product innovation. Journal of Product Innovation Management, 27(5), 673-689.

Veugelers, R., \& Cassiman, B. (2005). R\&D cooperation between firms and universities. Some empirical evidence from Belgian manufacturing. International Journal of Industrial Organization, 23(5-6), 355-379.

Von Hippel, E. (1988). The Sources of Innovation. New York: Oxford University Press. 
Von Hippel, E., \& Katz, R. (2002). Shifting innovation to users via toolkits. Management Science, 48(7), 821-833.

Woerter, M. (2012). Technological proximity between firms and universities and technology transfer. Journal of Technology Transfer, 37: 828-866 
Table 1. Frequencies of new, persistent and discontinued cooperation per partner type (2004-2011)

$\begin{array}{lrrrrrrrr}\text { Collaboration with: } & \text { Suppliers } & \text { \% } & \text { Customers } & \text { \% } & \text { Competitors } & \text { \% } & \text { Institutions } & \text { \% } \\ \text { Recent } & 838 & 21.6 & 247 & 26.3 & 238 & 26.8 & 931 & 21.7 \\ \text { Persistent } & 2069 & 53.3 & 453 & 48.3 & 368 & 41.4 & 2207 & 51.3 \\ \text { Discontinued } & 978 & 25.2 & 238 & 25.4 & 283 & 31.8 & 1162 & 27.0 \\ \text { Total } & 3885 & 100 & 938 & 100 & 889 & 100 & 4300 & 100\end{array}$




\section{Table 2. Descriptive statistics and pairwise correlations}

\begin{tabular}{|c|c|c|c|c|c|c|c|c|c|c|c|c|c|c|c|c|c|c|c|c|c|}
\hline & & $\begin{array}{l}\text { Me } \\
\text { an }\end{array}$ & SD & 1 & 2 & 3 & 4 & 5 & 6 & 7 & 8 & 9 & 10 & 11 & 12 & 13 & 14 & 15 & 16 & 17 & 18 \\
\hline 1 & Innovative performance $_{(\mathrm{t})}$ & 1.19 & 1.76 & & & & & & & & & & & & & & & & & & \\
\hline 2 & Innovative performance $_{(\mathrm{t}-1)}$ & 1.24 & 1.78 & 0.67 & & & & & & & & & & & & & & & & & \\
\hline 3 & Recent supplier & & & & & & & & & & & & & & & & & & & & \\
\hline & cooperation $_{(\mathrm{t}-1)}$ & 0.02 & 0.15 & 0.06 & 0.07 & & & & & & & & & & & & & & & & \\
\hline 4 & Recent customer & & & & & & & & & & & & & & & & & & & & \\
\hline 5 & $\begin{array}{l}\text { cooperation }_{(\mathrm{t}-1)} \\
\text { Recent competitor }\end{array}$ & 0.01 & 0.08 & 0.05 & 0.05 & 0.2 & & & & & & & & & & & & & & & \\
\hline 6 & $\begin{array}{l}\text { cooperation }_{(t-1)} \\
\text { Recent institutional }\end{array}$ & 0.01 & 0.08 & 0.04 & 0.04 & 0.17 & 0.23 & & & & & & & & & & & & & & \\
\hline 7 & $\begin{array}{l}\text { cooperation }_{(t-1)} \\
\text { Persistent supplier }\end{array}$ & 0.03 & 0.16 & 0.06 & 0.06 & 0.32 & 0.14 & 0.18 & & & & & & & & & & & & & \\
\hline 8 & $\begin{array}{l}\text { cooperation }_{(\mathrm{t}-1, \mathrm{t}-2)} \\
\text { Persistent customer }\end{array}$ & 0.05 & 0.21 & 0.12 & 0.11 & -0.03 & 0.10 & 0.08 & 0.05 & & & & & & & & & & & & \\
\hline 9 & $\begin{array}{l}\text { cooperation }_{(\mathrm{t}-1, \mathrm{t}-2)} \\
\text { Persistent competitor }\end{array}$ & 0.01 & 0.10 & 0.08 & 0.07 & 0.01 & -0.01 & 0.06 & 0.03 & 0.35 & & & & & & & & & & & \\
\hline 10 & $\begin{array}{l}\text { cooperation }_{(\mathrm{t}-1, \mathrm{t}-2)} \\
\text { Persistent institution }\end{array}$ & 0.01 & 0.09 & 0.08 & 0.07 & 0.00 & 0.03 & -0.01 & 0.01 & 0.29 & 0.32 & & & & & & & & & & \\
\hline 11 & $\begin{array}{l}\text { cooperation }_{(\mathrm{t}-1, \mathrm{t}-2)} \\
\text { Discontinued supplier }\end{array}$ & 0.05 & 0.22 & 0.12 & 0.12 & 0.06 & 0.07 & 0.08 & -0.04 & 0.50 & 0.26 & 0.25 & & & & & & & & & \\
\hline 12 & $\begin{array}{l}\text { cooperation }_{(\mathrm{t}-1, \mathrm{t}-2)} \\
\text { Discontinued customer }\end{array}$ & 0.02 & 0.15 & 0.04 & 0.04 & -0.02 & 0.01 & 0.01 & 0.01 & -0.03 & 0.00 & 0.00 & 0.04 & & & & & & & & \\
\hline 13 & $\begin{array}{l}\text { cooperation }_{(\mathrm{t}-1, \mathrm{t}-2)} \\
\text { Discontinued competitor }\end{array}$ & 0.01 & 0.07 & 0.03 & 0.04 & 0.01 & -0.01 & 0.01 & 0.01 & 0.07 & -0.01 & 0.01 & 0.06 & 0.23 & & & & & & & \\
\hline 14 & $\begin{array}{l}\text { cooperation }_{(t-1, t-2)} \\
\text { Discontinued institution }\end{array}$ & 0.01 & 0.08 & 0.03 & 0.03 & 0.01 & 0.01 & -0.01 & 0.01 & 0.07 & 0.04 & -0.01 & 0.06 & 0.19 & 0.27 & & & & & & \\
\hline & cooperation $_{(\mathrm{t}-1, \mathrm{t}-2)}$ & 0.03 & 0.16 & 0.04 & 0.04 & 0.02 & 0.02 & 0.02 & -0.03 & 0.03 & 0.01 & 0.00 & -0.04 & 0.33 & 0.15 & 0.19 & & & & & \\
\hline 15 & Firm size $_{(\mathrm{t}-1)}$ & 4.17 & 1.58 & 0.03 & 0.04 & 0.07 & 0.06 & 0.05 & 0.06 & 0.17 & 0.09 & 0.06 & 0.16 & 0.06 & 0.05 & 0.04 & 0.04 & & & & \\
\hline 16 & Innovation expenditures./sales $(\mathrm{t}-1)$ & 0.05 & 0.08 & 0.14 & 0.12 & 0.03 & 0.02 & 0.02 & 0.05 & 0.04 & 0.03 & 0.02 & 0.07 & 0.01 & 0.02 & 0.02 & 0.03 & -0.28 & & & \\
\hline 17 & Exporting Firm $_{(\mathrm{t}-1)}$ & 0.68 & 0.47 & 0.14 & 0.13 & 0.06 & 0.04 & 0.04 & 0.05 & 0.11 & 0.05 & 0.05 & 0.08 & 0.06 & 0.04 & 0.04 & 0.04 & 0.11 & -0.06 & & \\
\hline 18 & Resource constraints $_{(\mathrm{t}-1)}$ & 1.74 & 1.87 & -0.02 & -0.01 & -0.01 & -0.01 & 0.00 & 0.00 & -0.03 & -0.02 & -0.02 & -0.02 & -0.01 & -0.01 & -0.01 & -0.01 & -0.23 & 0.11 & -0.01 & \\
\hline 19 & Patents/R\&D $\mathrm{D}_{(\mathrm{t}-1)}$ & 0.03 & 0.40 & 0.02 & 0.03 & 0.00 & 0.00 & 0.00 & 0.00 & 0.00 & 0.00 & 0.00 & 0.00 & -0.01 & 0.00 & 0.00 & 0.00 & -0.02 & -0.01 & 0.01 & 0.00 \\
\hline
\end{tabular}

Note: The descriptive statistics are sample means for the years 2004-2011. The number of observations is 42896 . 
Table 3. Inter-temporal patterns of $R \& D$ Collaboration on innovative performance

\begin{tabular}{|c|c|c|}
\hline & Model 1 & Model 2 \\
\hline Recent supplier cooperation $(\mathrm{t}-1)$ & & $\begin{array}{c}0.077 \\
(0.049)\end{array}$ \\
\hline Recent customer cooperation $_{(t-1)}$ & & $\begin{array}{c}0.138 \\
(0.084)\end{array}$ \\
\hline Recent competitor cooperation $(t-1)$ & & $\begin{array}{c}0.047 \\
(0.086)\end{array}$ \\
\hline Recent institutional cooperation $_{(\mathrm{t}-1)}$ & & $\begin{array}{c}0.143 * * * \\
(0.047)\end{array}$ \\
\hline Persistent supplier cooperation $(\mathrm{t}-1, \mathrm{t}-2)$ & & $\begin{array}{c}0.117 * * * \\
(0.041)\end{array}$ \\
\hline Persistent customer cooperation $(\mathrm{t}-1, \mathrm{t}-2)$ & & $\begin{array}{c}0.168 * * \\
(0.077)\end{array}$ \\
\hline Persistent competitor cooperation ${ }_{(\mathrm{t}-1, \mathrm{t}-2)}$ & & $\begin{array}{c}0.229 * * * \\
(0.083)\end{array}$ \\
\hline Persistent institutional cooperation $(\mathrm{t}-1, \mathrm{t}-2)$ & & $\begin{array}{c}0.153 * * * \\
(0.038)\end{array}$ \\
\hline Discontinued supplier cooperation $_{(\mathrm{t}-1, \mathrm{t}-2)}$ & & $\begin{array}{c}0.085 \\
(0.052)\end{array}$ \\
\hline Discontinued customer cooperation $_{(\mathrm{t}-1, \mathrm{t}-2)}$ & & $\begin{array}{l}-0.016 \\
(0.095)\end{array}$ \\
\hline Discontinued competitor cooperation $_{(\mathrm{t}-1, \mathrm{t}-2)}$ & & $\begin{array}{c}0.135 \\
(0.089)\end{array}$ \\
\hline Discontinued institutional cooperation $_{(\mathrm{t}-1, \mathrm{t}-2)}$ & & $\begin{array}{c}0.053 \\
(0.045)\end{array}$ \\
\hline Innovative performance $_{(\mathrm{t}-1)}$ & $\begin{array}{c}0.646 * * * \\
(0.005)\end{array}$ & $\begin{array}{c}0.640 * * * \\
(0.005)\end{array}$ \\
\hline $\operatorname{Size}_{(\mathrm{t}-1)}$ & $\begin{array}{c}0.047 * * * \\
(0.004)\end{array}$ & $\begin{array}{c}0.035^{* * * *} \\
(0.004)\end{array}$ \\
\hline Innovation expenditures/sales $(t-1)$ & $\begin{array}{c}1.624 * * * \\
(0.090)\end{array}$ & $\begin{array}{c}1.502 * * * \\
(0.091)\end{array}$ \\
\hline${\text { Exporting } \text { Firm }_{(\mathrm{t}-1)}}$ & $\begin{array}{c}0.157 * * * \\
(0.015)\end{array}$ & $\begin{array}{c}0.142 * * * \\
(0.015)\end{array}$ \\
\hline Resource constraints $_{(\mathrm{t}-1)}$ & $\begin{array}{c}-0.010^{* * * *} \\
(0.003)\end{array}$ & $\begin{array}{c}-0.010^{* * * *} \\
(0.003)\end{array}$ \\
\hline Patents/R\&D $(t-1)$ & $\begin{array}{c}0.020 \\
(0.021)\end{array}$ & $\begin{array}{c}0.020 \\
(0.021)\end{array}$ \\
\hline Constant & $\begin{array}{l}-0.055 \\
(0.052)\end{array}$ & $\begin{array}{l}-0.023 \\
(0.053)\end{array}$ \\
\hline Number of firms & 9782 & 9782 \\
\hline Number of observations & 42896 & 42896 \\
\hline $\mathrm{R} 2$ & 0.46 & 0.47 \\
\hline Log-likelihood & -71852.38 & -71773.36 \\
\hline LR test of model fit improvement & & $158.05 * * *$ \\
\hline
\end{tabular}

Notes: 27 industry dummies and 5 year dummies included. Robust standard errors in parentheses. *Significant at $10 \%, * *$ Significant at $5 \%, * * *$ Significant at $1 \%$ 